\title{
Left Ventricular End Diastolic Pressure
}

National Cancer Institute

\section{Source}

National Cancer Institute. Left Ventricular End Diastolic Pressure. NCI Thesaurus. Code C120919.

The pressure within the left ventricle following the completion of diastolic filling, just prior to systole. 